\title{
The physical properties of fruits and the physiological quality of seeds of selected crambe genotypes
}

\author{
Jacek Kwiatkowski*, Michał Krzyżaniak, Dariusz Załuski, Mariusz J. Stolarski, Józef Tworkowski \\ Department of Plant Breeding and Seed Production, University of Warmia, Mazury in Olsztyn, Poland
}

\section{A R T I C L E I N F O}

\section{Keywords:}

Crambe

Seed quality

Vigor

Morphological properties of fruits/seeds

Varietal differences

\begin{abstract}
A B S T R A C T
Crambe fruits are abundant in oil that contains more than $50 \%$ of erucic acid which has many applications in chemical, cosmetic and food processing industries. Selected physical properties of fruits and the physiological quality of seeds of ten crambe genotypes, including eight new breeding lines and two cultivars, were evaluated. The analyzed traits varied significantly subject to weather conditions during the growing cycle. The results were used to identify three lines (Elst2007-2; Elst2007-3 and PRI-9104-71) with large and heavy fruits. Crambe seeds were characterized by high viability, but dormant seeds were also detected, and their proportions were determined by weather conditions during the growing cycle. Breeding line Elst2007-16 was characterized by a high proportion of dormant seeds in all years of the study, and it was least influenced by environmental conditions. The germination capacity of the evaluated crambe genotypes was determined by the number of fresh nongerminating seeds. Genotypes Elst2007-2; Elst2007-3 and PRI-9104-71 were characterized by large and heavy fruits as well as the highest seed vigor. Evaluations of the physical properties of crambe fruits and the physiological quality of crambe seeds contribute to the effectiveness of breeding programs by selecting genotypes with large and high-quality seeds.
\end{abstract}

\section{Introduction}

Crambe (Crambe abyssinica Hochst. ex R. E. Fr.) is an annual oilseed plant of the family Brassicaceae that is native to the Mediterranean Region and eastern Africa (Falasca et al., 2010). Crambe fruits are siliques composed of two segments, where only the top seed-containing segment is fully developed (Dorywalski et al., 1956; Młodzianowska, 1961). Crambe fruits are abundant in oil that contains even more than $54 \%$ of erucic acid which has many applications in chemical, cosmetic and food processing industries and is used in the production of biodiesel, nylon derivatives, lubricants, rubber additives and hydraulic fluids (Falasca et al., 2010; Lazzeri et al., 1994; Wang et al., 2000). Crambe meal is used in the production of food and feed (Prakhova, 2013; Zhu, 2016). Research into crambe as an agricultural crop was initiated in 1932 in Russia, where the species was introduced for cultivation in the late 1930s (Byszewski et al., 1978; Prakhova, 2013). In the 1940s and 1950s, crambe breeding programs were also initiated in other countries, including Poland and Sweden (Falasca et al., 2010; Grabiec, 1958; Meijer et al., 1999). In 1958, research into crambe began in the USA as part of a program dedicated to the search for new species of industrial crops (Lessman, 1990; Wolff, 1966). At present, crambe is regarded as a potential renewable source of non-edible vegetable oil and an alternative fuel that does not compete with oilseed food crops (Bassegio et al., 2016; Falasca et al., 2010; Stolarski et al., 2018; Zanetti et al., 2016, 2013). The interest in crambe as an industrial crop has prompted many countries, mainly the USA, Netherlands and Brazil, to develop breeding programs with the aim of improving the quantitative and qualitative parameters of this plant species (LaraFioreze et al., 2013; Mastebroek and Lange, 1997; Oliveira et al., 2018). Efforts are being made to increase seed yields, the oil content of seeds, the erucic acid content of oil, to decrease glucosinolate levels and improve crambe's resistance to diseases caused by Alternaria and Sclerotinia (Lara-Fioreze et al., 2016). Breeding programs also aim to improve the physiological quality of seeds, in particular to overcome seed dormancy (Knights, 2002). A certain proportion of crambe seeds present post-harvest dormancy. This is a characteristic feature of recently domesticated species which obstructs reliable evaluations of seed performance and prevents farmers from achieving the desired plant density and high yields (Carlson et al., 1996; Oliveira et al., 2014). According to Lara-Fioreze et al. (2013), an evaluation of the physiological quality of seeds in germination and vigor tests can provide a basis for analyzing genetic variability, which is low in the germplasm of crambe seeds and inhibits breeding progress.

The aim of this study was to evaluate variation in the physical

\footnotetext{
* Corresponding author.

E-mail address: jacek.kwiatkowski@uwm.edu.pl (J. Kwiatkowski).
} 
Table 1

Crambe genotypes evaluated in the study (2015-2018).

\begin{tabular}{lll}
\hline Genotype number & Name & Form \\
\hline 1 & Elst2007-3 & line \\
2 & Elst2007-9 & line \\
3 & Elst2007-16 & line \\
4 & Elst2007-8 & line \\
5 & Elst2007-7 & line \\
6 & Elst2007-2 & line \\
7 & PRI-9104-71 & line \\
8 & PRI-9104-100 & line \\
9 & Nebula & cultivar \\
10 & Galactica & cultivar \\
\hline
\end{tabular}

properties of fruits and the physiological quality of seeds of selected crambe genotypes in four consecutive growing cycles in north-eastern Europe.

\section{Materials and methods}

\subsection{Seeds}

Crambe seeds used in the study were grown during a field experiment conducted in 2015-2018 at the Agricultural Experiment Station in Łężany $\left(53^{\circ} 59^{\prime} \mathrm{N}, 21^{\circ} 09^{\prime} \mathrm{E}\right)$, north-eastern Poland, which constitutes the property of the University of Warmia and Mazury in Olsztyn. The field experiment had a randomized block design with 4 replicates. Plot area was $9 \mathrm{~m}^{2}$ (harvest area $-6 \mathrm{~m}^{2}$ ). Ten crambe genotypes ( 8 lines and 2 cultivars) developed by the Wageningen University and Research Center in the Netherlands were used in the experiment (Table 1). Each year after harvest, representative samples of crambe fruits with an average weight of around $600 \mathrm{~g}$ each were drawn from seed lot of each genotype for laboratory analyses.

\subsection{Evaluation of the physical properties of fruits}

Thousand-fruit weight, bulk density of seeds/fruits, fruit size fractions, and fruit uniformity were evaluated. Thousand-fruit weight was determined in 4 replicates for each genotype by collecting 8 sub-samples of 100 fruits each per replicate (ISTA, 2013). The fruits in every sub-sample were weighed to the nearest $0.0001 \mathrm{~g}$ (HR 60, A\&D Company Limited, Japan). When the coefficient of variation did not exceed $4 \%$, the average from sub-sample measurements was multiplied by 10 . Bulk density was calculated in 4 replicates for each genotype, in accordance with PN EN ISO 7971-3:2010 (2010)PN EN ISO 7971-3, 2010PN EN ISO 7971-3:2010 (2010). Fruit size fractions were determined by passing $100 \mathrm{~g}$ samples through a set of sieves with round openings $(\varphi=3.0,3.25$ and $3.5 \mathrm{~mm})$ for $3 \mathrm{~min}$ to produce 4 fruit fractions with diameters of $\leq 3.0 \mathrm{~mm}, 3.0 \geq 3.25 \mathrm{~mm}, 3.25 \geq 3.5 \mathrm{~mm}$ and $>3.5 \mathrm{~mm}$. Fruit size fractions were determined in 4 replicates for each genotype. Batch uniformity was expressed as the largest sum of two successive fractions in the batch.

\subsection{Seed germination}

A germination test was conducted on 100 crambe fruits of every genotype which were spread on filter paper soaked with distilled water in plastic boxes measuring $21 \times 12 \times 3 \mathrm{~cm}$. The seeds of every genotype were tested in 4 replicates. Plastic boxes were placed in a germination chamber (Sanyo MLR-350 T). Seeds were germinated in darkness at a constant temperature of $20^{\circ} \mathrm{C}$ for 7 days. The number of germinated seeds (with minimum radicle length of $3 \mathrm{~mm}$ ) was counted each day. Germination energy (GE, percentage of seeds germinated after 4 days), germination capacity (GC, after 7 days) and selected germination parameters, including mean germination time of one seed (MGT,
Pieper, 1952), germination vigor index (GVI) (Maguire, 1962) and germination value (GV) (Czabator, 1962), were calculated.

\subsection{Evaluation of seed vigor}

Seed vigor was evaluated in the controlled deterioration test (CDT). One hundred seeds of every crambe genotype were tested in 4 replicates. Crambe fruits were brought to a moisture content of $20 \%$ and were stored in air-tight tubes in a laboratory heater at a temperature of $45^{\circ} \mathrm{C}$ for $24 \mathrm{~h}$. Seed germination was evaluated in the germination test described in section 2.3 .

\subsection{Statistical analysis}

The results were processed statistically using GLM mixed model with genotypes as fixed effect and experimental years and replicates nested within years as the random effects. The significance of differences between means was evaluated by Tukey's test at $P \leq 0.05$. Principal component analysis (PCA) was performed based on five parameters (1000 fruit weight, hectoliter mass, percentage of fruits with a diameter of $3.25 \geq 3.5 \mathrm{~mm}$, germination capacity, and the percentage of fresh non-germinating seeds). The results of PCA were used to identify genotypes with outstanding characteristics. All analyses were performed in Statistica 13 (TIBCO Software Inc, 2017).

The analysis of variance of all tested parameters (thousand-fruit weight, bulk density of seeds/fruits, fruit uniformity, germination energy, germination capacity, non-germinated (fresh) seeds, mean germination time, germination vigor index, germination value and germination energy and germination capacity after CDT) revealed significant effects of genotype, year, and genotype $\times$ year interaction at $P \leq 0.001$. However, the aim of the study was to determine differences between the analyzed genotypes and to identify genotypes with the most desirable physical and physiological properties of seeds; therefore, only the main effects were discussed, whereas the interaction between the above factors was disregarded.

\section{Results}

\subsection{Weather conditions in growing cycles}

Weather conditions during the growing cycle of 2015-2018 are presented in Table 2. Precipitation levels in growing cycles were evaluated with the use of Selyaninov's hydrothermal coefficient (HTC) (Wilhite and Pulwarty, 2017) which was calculated by dividing total precipitation in the analyzed period by total temperature (T) during

Table 2

Precipitation and temperature during growth stages of crambe in four consecutive growing cycles (2015-2018).

\begin{tabular}{|c|c|c|c|c|c|c|}
\hline \multirow[t]{2}{*}{ Specification } & \multirow[t]{2}{*}{ Years } & \multicolumn{5}{|c|}{ Growth stages } \\
\hline & & A & B & $\mathrm{C}$ & $\mathrm{D}$ & $\mathrm{E}$ \\
\hline \multirow[t]{4}{*}{ Mean temperature $\left({ }^{\circ} \mathrm{C}\right)$} & 2015 & 10.9 & 16.1 & 16.4 & 18.3 & 14.7 \\
\hline & 2016 & 11.0 & 19.2 & 17.3 & 19.2 & 15.4 \\
\hline & 2017 & 10.8 & 17.0 & 17.2 & 19.7 & 14.8 \\
\hline & 2018 & 15.8 & 18.7 & 17.7 & 20.7 & 17.8 \\
\hline \multirow[t]{4}{*}{ Precipitation (mm) } & 2015 & 72.3 & 1.7 & 44.9 & 100.9 & 219.8 \\
\hline & 2016 & 108.3 & 24.9 & 167.8 & 100.2 & 401.1 \\
\hline & 2017 & 70.6 & 6.8 & 85.8 & 72.0 & 235.2 \\
\hline & 2018 & 48.4 & 2.6 & 20.0 & 64.4 & 135.4 \\
\hline \multirow[t]{4}{*}{ HTC } & 2015 & 1.35 & 0.08 & 1.19 & 1.58 & 1.25 \\
\hline & 2016 & 2.05 & 1.18 & 2.15 & 2.49 & 2.09 \\
\hline & 2017 & 1.12 & 0.67 & 1.31 & 1.52 & 1.27 \\
\hline & 2018 & 0.71 & 0.15 & 0.50 & 1.07 & 0.74 \\
\hline
\end{tabular}

A - sowing to stem elongation, B - stem elongation to beginning of flowering, C - beginning of flowering to end of flowering, D - end of flowering to full ripeness, E - sowing to full ripeness, HTC - Selyaninov's hydrothermal coefficient. 
a)

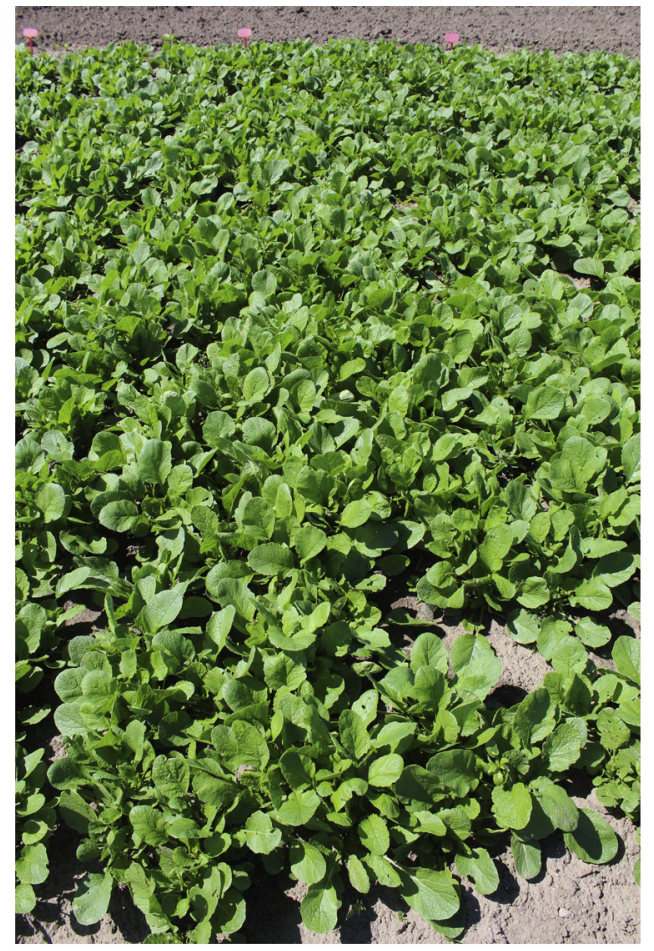

c)

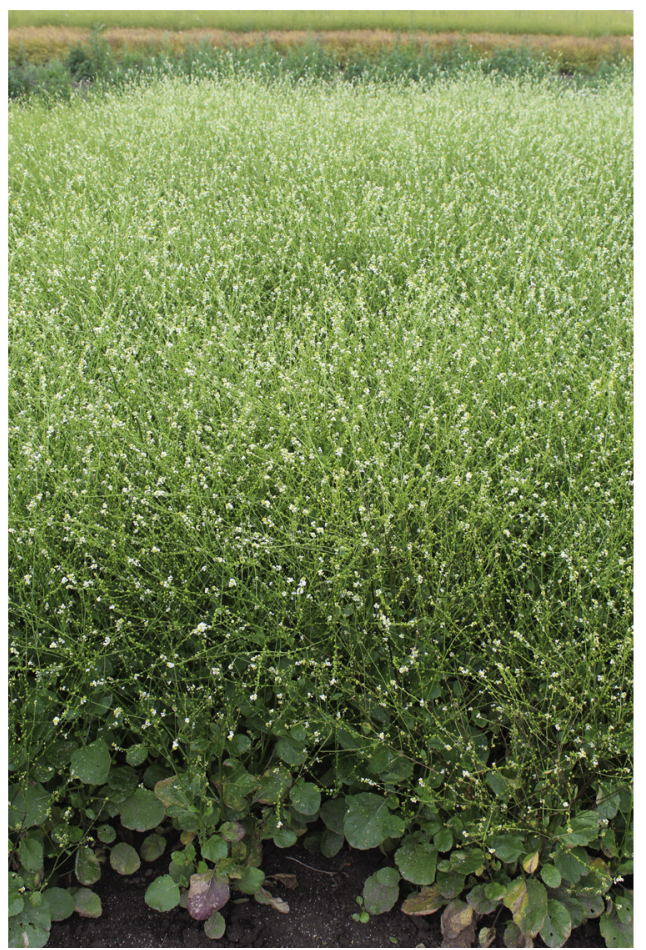

b)

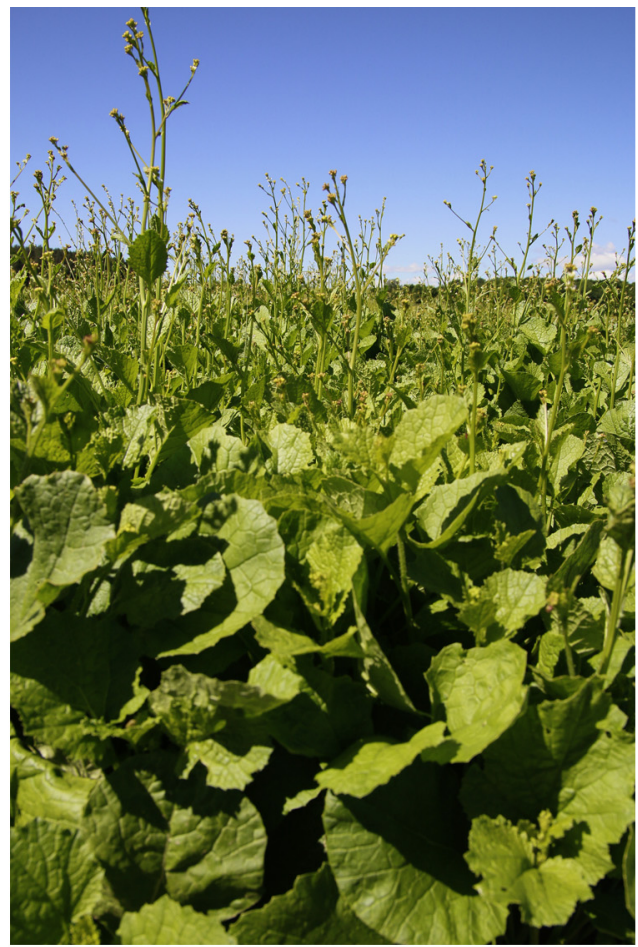

d)

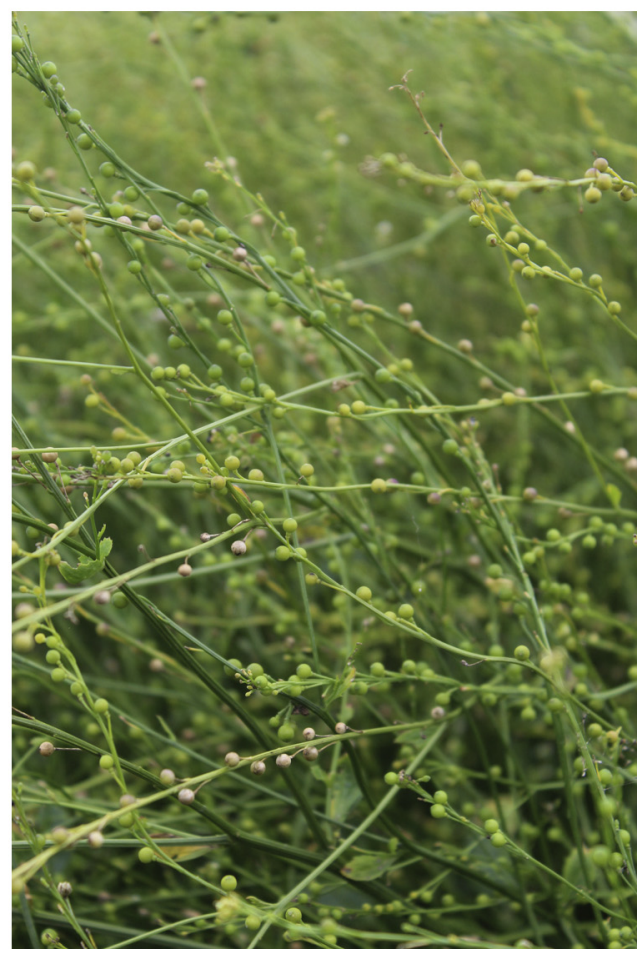

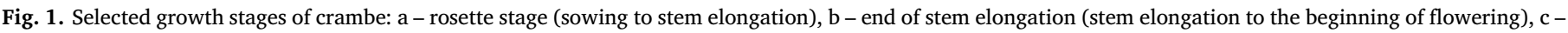
end of flowering (beginning of flowering to end of flowering), $\mathrm{d}$ - seed ripening (end of flowering to full seed ripeness).

that period, and the resulting quotient was multiplied by 10: HTC $=$ $(\Sigma \mathrm{P} / \Sigma \mathrm{T}) \times 10$ (Selyaninov, 1928). Growing cycles were divided into the following categories based on the calculated values of HTC: extremely dry $-k \leq 0.40$; very dry $-0.41<k \leq 0.70$; dry $-0.71<k \leq 1.0$; quite dry $-1.01<k \leq 1.30$; optimal $-1.31<k \leq 1.60$; quite wet $-1.61<k$ $\leq 2.0$; wet $-2.01<k \leq 2.5$; very wet $-2.51<k \leq 3.0$; extremely wet $-k>3.01$ (Skowera, 2014).

Weather conditions varied considerably in the analyzed growing cycles. Based on the calculated values of HTC, 2015 and 2017 were characterized by nearly optimal precipitation and temperature.
Favorable weather conditions for the growth and development of crambe persisted throughout the growing cycles of 2015 and 2017, excluding the second stage of vegetative growth between stem elongation and the beginning of flowering (Fig. 1). This stage was characterized by precipitation deficit, in particular in 2015, but its effects were somewhat alleviated by residual water from previous periods and moderate temperatures in both years (Table 2). The growing cycle of 2016 was wet, and precipitation was particularly high in the second half of the generative growth phase, i.e. between the end of flowering and full ripeness. The growing cycle of 2016 was also warm, with the 
a)

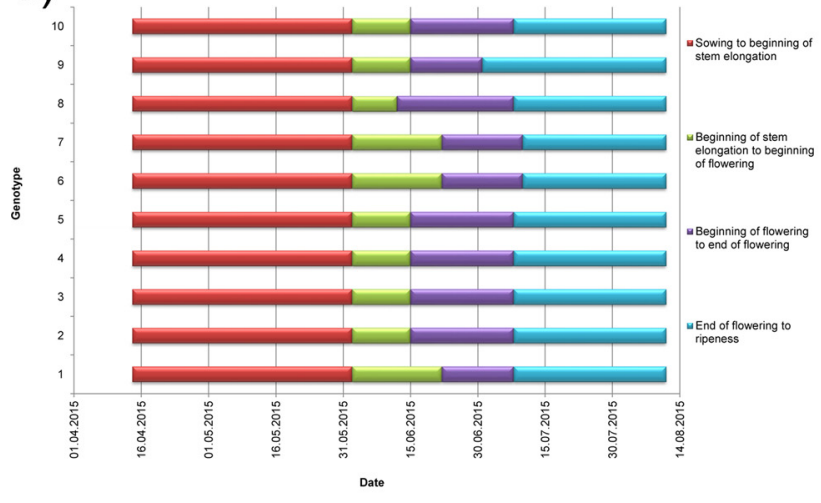

2017

c)

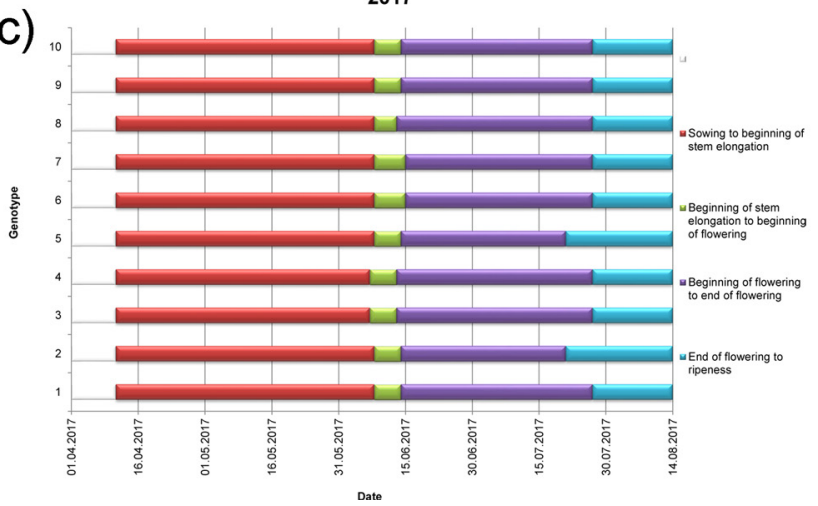

b)

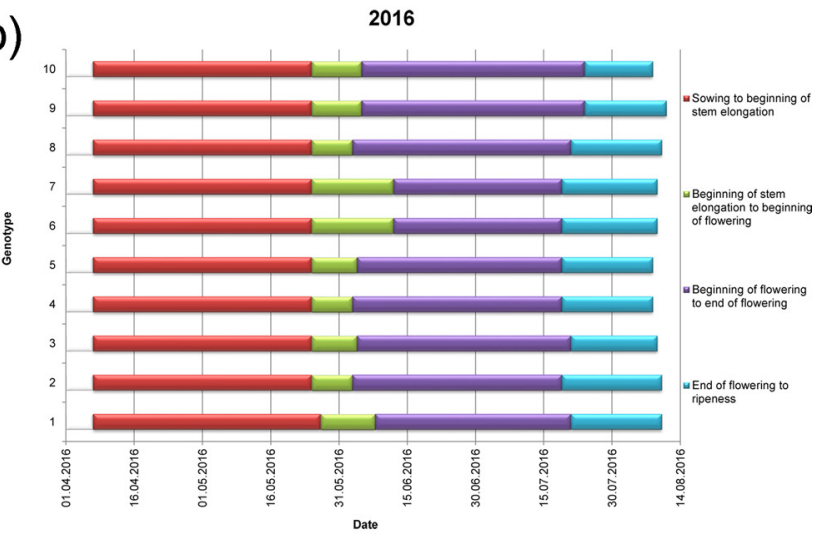

2018

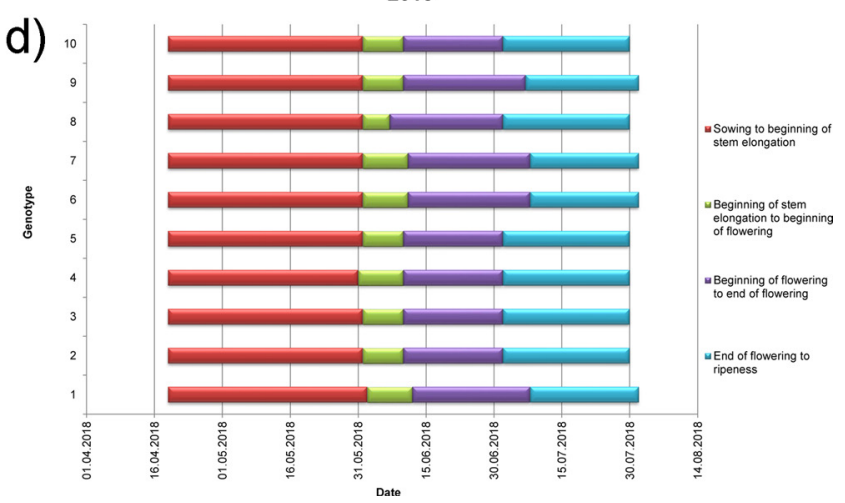

Fig. 2. Duration of growth stages in the evaluated crambe accessions during four consecutive years of cultivation.

highest total average temperature during the study. Weather conditions were least favorable in the growing cycle of 2018 due to precipitation deficit in all stages of plant development, in particular between stem elongation and the end of flowering. In 2018, precipitation was highest in the last stages of generative growth, and it was accompanied by high temperatures (Table 2).

The variations in weather conditions across growing cycles (such as prolonged initial growth due to ground frost in 2017) exerted a greater influence on the growth and development of crambe than varietal traits. The evaluated genotypes were characterized by growing cycles of similar length (Fig. 2). The vegetative stage was somewhat prolonged and the generative phase was somewhat shorter in breeding lines 1, 6 and 7.

\subsection{Physical properties of fruits}

The thousand-fruit weight of crambe reached $7.0 \mathrm{~g}$ on average during the 4-year experiment, and was significantly higher in 2016 than in the remaining years (Table 3). Crambe fruits harvested in 2015 were characterized by the lowest weight, which was $1.23 \mathrm{~g}$ lower $(16 \%)$ than in 2016. Breeding lines 6, 7 and 1 were characterized by the heaviest fruits. Fruit weight also exceeded $7 \mathrm{~g}$ in lines 3 and 4 . The lightest fruits were noted in line 2 .

The bulk density of crambe fruits was negatively correlated with 1000 fruit weight (Tables 3 and 5). Bulk density was highest in crambe fruits harvested in 2015, whereas lower values of this parameter were noted in fruits harvested in 2016 and 2017. Bulk density was lowest in the fruits of breeding lines with the highest 1000 fruit weight. The only exceptions were lines 3 and 4 whose fruits were characterized by relatively high weight and bulk density.

Fruit weight was correlated with fruit size (Table 6). In 2016, the proportion of fruits with a diameter of $>3.5 \mathrm{~mm}$ was significantly higher than the proportion of fruits from the remaining size fractions (Fig. 3), which decreased fruit uniformity in the batch due to more even
Table 3

Thousand-seed weight, bulk density of fruits, and fruit uniformity of 10 crambe genotypes during four consecutive years of cultivation (2015-2018) (means for years and means for genotypes).

\begin{tabular}{llll}
\hline Parameter & $\begin{array}{l}\text { Thousand seed } \\
\text { weight }[\mathrm{g}]\end{array}$ & $\begin{array}{l}\text { Bulk density of fruits } \\
{\left[\mathrm{g} \cdot \mathrm{dm}^{-3}\right]}\end{array}$ & $\begin{array}{l}\text { Uniformity of fruits } \\
{[\%]}\end{array}$ \\
\hline Years & & & \\
2015 & $6.45 \mathrm{D}$ & $331 \mathrm{~A}$ & $87 \mathrm{~A}$ \\
2016 & $7.68 \mathrm{~A}$ & $301 \mathrm{C}$ & $58 \mathrm{D}$ \\
2017 & $7.16 \mathrm{~B}$ & $301 \mathrm{C}$ & $70 \mathrm{C}$ \\
2018 & $6.77 \mathrm{C}$ & $312 \mathrm{~B}$ & $74 \mathrm{~B}$ \\
Genotype & & & \\
1 & $7.33 \mathrm{ab}$ & $293 \mathrm{f}$ & $68 \mathrm{e}$ \\
2 & $6.48 \mathrm{e}$ & $308 \mathrm{de}$ & $73 \mathrm{~b}$ \\
3 & $7.14 \mathrm{bc}$ & $336 \mathrm{a}$ & $73 \mathrm{~b}$ \\
4 & $7.22 \mathrm{bc}$ & $323 \mathrm{bc}$ & $70 \mathrm{~cd}$ \\
5 & $6.68 \mathrm{de}$ & $303 \mathrm{e}$ & $72 \mathrm{bc}$ \\
6 & $7.66 \mathrm{a}$ & $297 \mathrm{f}$ & $69 \mathrm{de}$ \\
7 & $7.48 \mathrm{ab}$ & $296 \mathrm{f}$ & $68 \mathrm{e}$ \\
8 & $6.59 \mathrm{de}$ & $309 \mathrm{de}$ & $77 \mathrm{a}$ \\
9 & $6.88 \mathrm{~cd}$ & $327 \mathrm{~b}$ & $73 \mathrm{~b}$ \\
10 & $6.70 \mathrm{de}$ & $321 \mathrm{c}$ & $78 \mathrm{a}$ \\
\hline
\end{tabular}

Means with the same letters do not differ significantly at $P \leq 0.05$ in Tukey's HSD test; lower case letters denote differences between genotypes; upper case letters denote differences between seasons.

distribution of variously sized fruits (Table 3). Very large and large fruits were the predominant fractions $(>3.25 \mathrm{~mm})$. Fruit uniformity was highest in 2015 due to a predominance of the smallest fruits $(<3.25 \mathrm{~mm})$.

Cultivar Galactica and breeding line 8 were characterized by the highest fruit uniformity and high proportions of small and very small fruits. Fruit uniformity was lowest in lines 1, 6 and 7 which were characterized by the highest proportion of large and very large fruits, and the lowest proportion of very small fruits in all years of the 
Table 4

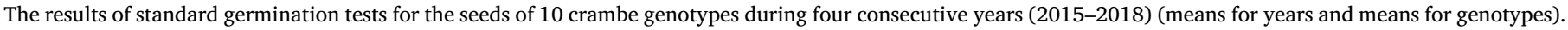

\begin{tabular}{|c|c|c|c|c|c|c|}
\hline Parameter & Germination energy [\%] & $\begin{array}{l}\text { Germination capacity } \\
{[\%]}\end{array}$ & $\begin{array}{l}\text { Non-germinated (fresh) seeds } \\
{[\%]}\end{array}$ & $\begin{array}{l}\text { Mean germination time } \\
\text { [days] }\end{array}$ & Germination vigor index & Germination value \\
\hline \multicolumn{7}{|l|}{ Years } \\
\hline 2015 & $95 \mathrm{~A}$ & $96 \mathrm{~A}$ & $2 \mathrm{C}$ & $2.16 \mathrm{~B}$ & $45.9 \mathrm{~A}$ & $562 \mathrm{~A}$ \\
\hline 2016 & $83 \mathrm{~B}$ & $84 \mathrm{~B}$ & 13B & $2.20 \mathrm{~B}$ & $40.2 B$ & $428 \mathrm{~B}$ \\
\hline 2017 & 77C & $78 \mathrm{C}$ & $20 \mathrm{~A}$ & $2.29 \mathrm{~A}$ & $35.8 \mathrm{C}$ & $346 \mathrm{D}$ \\
\hline 2018 & $84 \mathrm{~B}$ & $85 B$ & $12 \mathrm{~B}$ & $2.32 \mathrm{~S}$ & $39.6 \mathrm{~B}$ & $376 \mathrm{C}$ \\
\hline \multicolumn{7}{|l|}{ Genotype } \\
\hline 1 & $87 a b$ & $88 \mathrm{ab}$ & $9 b c$ & $2.28 \mathrm{a}$ & $40.6 \mathrm{abc}$ & $444 \mathrm{ab}$ \\
\hline 2 & $79 d$ & $80 \mathrm{~d}$ & $17 \mathrm{a}$ & $2.18 \mathrm{~b}$ & $38.6 \mathrm{~cd}$ & $393 c d$ \\
\hline 3 & $76 d$ & $77 d$ & $20 \mathrm{a}$ & $2.28 \mathrm{a}$ & $36.0 \mathrm{e}$ & $337 \mathrm{e}$ \\
\hline 4 & $80 \mathrm{~cd}$ & $80 \mathrm{~cd}$ & $19 \mathrm{a}$ & $2.25 \mathrm{ab}$ & 37.5de & 375de \\
\hline 5 & $90 \mathrm{a}$ & $91 \mathrm{a}$ & $8 \mathrm{bc}$ & $2.23 \mathrm{ab}$ & $43.2 \mathrm{a}$ & $477 a$ \\
\hline 6 & $90 a$ & $90 a$ & $7 c$ & $2.26 \mathrm{ab}$ & $42.2 \mathrm{abc}$ & $461 \mathrm{ab}$ \\
\hline 7 & $89 a$ & $90 a$ & $7 c$ & $2.23 \mathrm{ab}$ & $42.8 \mathrm{a}$ & $476 a$ \\
\hline 8 & $88 a b$ & $89 a b$ & $10 \mathrm{bc}$ & $2.20 \mathrm{ab}$ & $42.3 \mathrm{a}$ & $457 \mathrm{ab}$ \\
\hline 9 & $84 b c$ & $85 b c$ & $12 b$ & $2.24 \mathrm{ab}$ & 39.7bcd & 418bcd \\
\hline 10 & $87 a b$ & $88 a b$ & $9 b c$ & $2.27 \mathrm{ab}$ & $40.9 \mathrm{abc}$ & $442 \mathrm{abc}$ \\
\hline
\end{tabular}

Means with the same letters do not differ significantly at $P \leq 0.05$ in Tukey's HSD test; lower case letters denote differences between genotypes; upper case letters denote differences between seasons.

Table 5

Seed germination after the controlled deterioration test (CDT) of 10 crambe genotypes during four consecutive years (2015-2018) (means for years and means for genotypes).

\begin{tabular}{lll}
\hline Parameter & Germination energy [\%] & Germination capacity [\%] \\
\hline Years & & \\
2015 & $49 \mathrm{AB}$ & $50 \mathrm{AB}$ \\
2016 & $46 \mathrm{~B}$ & $48 \mathrm{~B}$ \\
2017 & $53 \mathrm{~A}$ & $53 \mathrm{~A}$ \\
2018 & $49 \mathrm{~B}$ & $51 \mathrm{AB}$ \\
Genotype & & \\
1 & $71 \mathrm{a}$ & $74 \mathrm{a}$ \\
2 & $44 \mathrm{de}$ & $45 \mathrm{de}$ \\
3 & $28 \mathrm{f}$ & $29 \mathrm{f}$ \\
4 & $38 \mathrm{e}$ & $38 \mathrm{e}$ \\
5 & $57 \mathrm{bc}$ & $58 \mathrm{bc}$ \\
6 & $62 \mathrm{~b}$ & $64 \mathrm{~b}$ \\
7 & $64 \mathrm{ab}$ & $66 \mathrm{~b}$ \\
8 & $38 \mathrm{e}$ & $39 \mathrm{e}$ \\
9 & $39 \mathrm{e}$ & $41 \mathrm{e}$ \\
10 & $49 \mathrm{~cd}$ & $52 \mathrm{~cd}$ \\
\hline
\end{tabular}

Means with the same letters do not differ significantly at $P \leq 0.05$ in Tukey's HSD test; lower case letters denote differences between genotypes; upper case letters denote differences between seasons. experiment (Fig. 3).

\subsection{Seed germination and vigor}

Crambe seeds germinated rapidly, and maximum potential of germination peaked within 3-4 days during the test (up to the first counting - GE). The highest germination capacity was noted in seeds harvested in 2015, and the lowest - in seeds harvested in 2017. The observed differences in germination capacity resulted mainly from the high proportion of fresh non-germinating seeds. Seed viability in all years of the study was estimated at $97-98 \%$ when the above differences were taken into account (Table 4).

Most of the evaluated crambe genotypes were characterized by high germination capacity. The highest germination capacity and the smallest number of fresh non-germinating seeds were noted in lines 5, 6 and 7 in all years of the study. Genotypes 2, 3 and 4 were characterized by a high proportion of dormant seeds.

The average germination time was 2.24 days. Crambe seeds harvested in 2015 and 2016 germinated significantly more rapidly than those harvested in the remaining years, and line 2 seeds were characterized by significantly shorter germination time than the seeds of lines 1 and 3, but the observed differences spanned hours $(2-4 \mathrm{~h})$ rather than days.

The remaining germination parameters were bound by highly significant positive correlations with the percentage of germinated seeds. Differences in germination rates could not be captured due to very short

Table 6

Matrix of correlation coefficients between selected parameters of crambe fruits/seeds.

\begin{tabular}{|c|c|c|c|c|c|c|c|c|c|c|c|c|}
\hline Variable & $\mathrm{BD}$ & $>3.5 \mathrm{~mm}$ & $3.25-3.5 \mathrm{~mm}$ & $3.0-3.25 \mathrm{~mm}$ & $<3.0 \mathrm{~mm}$ & Uniformity & GE & GC & MGT & GVI & GV & $\mathrm{CDT}^{1}$ \\
\hline Thousand fruit weight - TFW & $-0.50^{* * *}$ & $0.79^{* * *}$ & $0.74^{* * *}$ & $-0.56^{* * *}$ & $-0.79 * * *$ & $-0.84^{* * *}$ & -0.28 & -0.27 & 0.16 & -0.28 & -0.26 & 0.23 \\
\hline Bulk density - BD & & $-0.59 * * *$ & $-0.72^{* * *}$ & $0.46^{* *}$ & $0.71 * * *$ & $0.64 * * *$ & 0.18 & 0.17 & -0.19 & 0.18 & 0.22 & $-0.59^{* * *}$ \\
\hline$>3.5 \mathrm{~mm}$ & & & $0.55^{* * *}$ & $-0.84 * * *$ & $-0.62^{* * *}$ & $-0.80^{* * *}$ & -0.11 & -0.10 & -0.06 & -0.08 & -0.05 & 0.26 \\
\hline $3.25-3.5 \mathrm{~mm}$ & & & & $-0.38^{*}$ & $-0.95^{* * *}$ & $-0.64^{* * *}$ & -0.29 & -0.27 & $0.38^{*}$ & $-0.32^{*}$ & $-0.35^{*}$ & $0.62^{* * *}$ \\
\hline $3.0-3.25 \mathrm{~mm}$ & & & & & 0.30 & $0.58 * * *$ & 0.03 & 0.02 & -0.01 & 0.03 & 0.01 & -0.18 \\
\hline$<3.0 \mathrm{~mm}$ & & & & & & $0.71^{* * *}$ & 0.29 & 0.28 & -0.27 & 0.30 & $0.31^{*}$ & $-0.57^{* * *}$ \\
\hline Uniformity of fruit size & & & & & & & $0.47^{* *}$ & $0.46^{* *}$ & -0.16 & $0.43^{* *}$ & $0.44^{* *}$ & -0.16 \\
\hline Germination energy - GE & & & & & & & & $1.00^{* * * *}$ & $-0.48^{* *}$ & $0.98^{* * *}$ & $0.94^{* * *}$ & 0.16 \\
\hline Germination capacity - GC & & & & & & & & & $-0.46^{* *}$ & $0.97^{* * *}$ & $0.94^{* * *}$ & 0.18 \\
\hline $\begin{array}{l}\text { Mean germination time - } \\
\text { MGT }\end{array}$ & & & & & & & & & & $-0.63^{* * *}$ & $-0.71^{* * *}$ & 0.15 \\
\hline $\begin{array}{l}\text { Germination vigor index - } \\
\text { GVI }\end{array}$ & & & & & & & & & & & $0.97^{* * *}$ & 0.12 \\
\hline Germination value - GV & & & & & & & & & & & & 0.14 \\
\hline
\end{tabular}

("significant at $P \leq 0.05$; **significant at $P \leq 0.01$; ***significant at $P \leq 0.001 ;{ }^{1} \mathrm{CDT}$ - controlled deterioration test). 


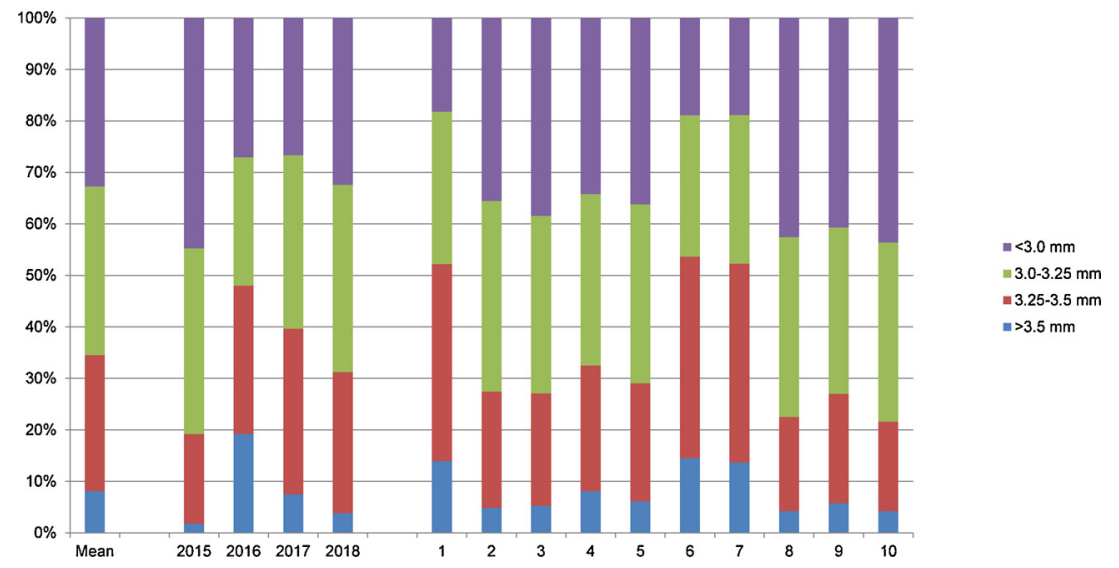

Fig. 3. Size fractions of crambe seeds in four consecutive growing cycles (means for years and means for genotypes).

germination times in all genotypes and all years of the study.

Germination capacity decreased to approximately $50 \%$ after the controlled deterioration test and was highly stable across years. The greatest decrease was noted in the seeds harvested in 2015 due to very high germination capacity before the test. Crambe seeds harvested in 2017 were characterized by the highest germination capacity after the controlled deterioration test and the lowest decrease in germination capacity due to low baseline values (Table 5).

Principal component analysis confirmed the highest 1000 fruit weight and the highest proportion of very large seeds $(>3.25 \mathrm{~mm})$ in genotypes 6, 7 and 1. It also demonstrated a higher proportion of fresh non-germinating seeds in genotype 3 and, in selected years (2016-2018), also in genotype 4 (Fig. 4). In each year, PC1 and PC2 explained $80.47 \%$ (2017) to $94.98 \%$ (2018) of variance. This result indicates that the analyzed relationships were statistically significant. Therefore, it should be assumed that they were not random or accidental.

\section{Discussion}

The physiological quality of crambe fruits should be analyzed in detail to guarantee success in the production of crambe seeds and oil. Based on the results of a long-term field study, Fontana et al. (1998) concluded that seed germination and seedling emergence are the critical stages in the growth and development of crambe. Crambe is characterized by high germination capacity ( $>90 \%$ ) under laboratory conditions, but this parameter could be compromised under exposure to varied weather conditions in the field. In crambe, seedling emergence, plant density, the number of seeds per plant, and 1000 seed weight are the critical determinants of seed and oil yield because they affect final plant density. Seedling emergence and plant density are closely and highly correlated due to infrequent decline of emerged seedlings (Fontana et al., 1998). Seed vigor influences plant density as well as plant growth, development and yields (Soares et al., 2018). Fontana et al. (1998) demonstrated that high seed vigor, which supports the achievement of the desired plant density in the field, compensated for the reduced oil content of seeds across analyzed accessions and influenced oil yield per unit area. For this reason, breeding programs should aim to improve the physiological quality of crambe seeds, which will stabilize plant density under varied field conditions and improve seed and oil yields. Plant density per unit area determines the number of fruits per plant. However, a negative correlation between these yield components weakens their direct effect on seed and oil yields (Fontana et al., 1998; Jankowski and Budzyński, 2003).

Considerable progress has been made in breeding new crambe varieties despite certain species-related limitations (Mastebroek and Lange, 1997). New varieties and breeding lines with enhanced quality traits have been developed, and their performance under varied field conditions should be evaluated. Vollmann and Ruckenbauer (1993) and Mastebroek and Lange (1997) demonstrated that crambe yields are highly sensitive to habitat conditions.

The results of the present study indicate that crambe plants produced the largest and heaviest fruits in years characterized by high total precipitation and high temperature during flowering as well as high precipitation and moderate temperatures during seed ripening (2016 and 2017). Environmental conditions exerted a far greater influence on fruit size and weight than genotype, but accessions 1, 6 and 7 produced large and heavy fruits in all years of the study. In these genotypes, the generative phase of plant growth was somewhat delayed and flowering was somewhat shortened in the climate of Central-Eastern Europe. Meijer et al. (1999) reported that 1000 seed weight was considerably affected by high insolation during seed filling. In their study, seed weight was not affected by plant density, which suggests that this parameter is determined by the amount of solar radiation intercepted by siliques. The above authors noted that the seeding rate exerted a much greater influence on the number of seeds per plant, in particular in early maturing genotypes. In many species, 1000 seed weight is regarded as a critical yield component, but Fontana et al. (1998) and Jankowski and Budzyński (2003) demonstrated that this trait was not correlated with seed yield or oil yield in crambe, which is why selective breeding for higher 1000 seed weight is unlikely to increase yields in this species. Fontana et al. (1998) reported a positive correlation between fruit hectoliter mass and fruit yield, and suggested that this trait is an important yield component in crambe. Hectoliter mass (volume of seeds/fruits per unit) is generally negatively correlated with 1000 seed/ fruit weight, which was also demonstrated in this study $(r=-0.50)$. The only exception was genotype 3 which was characterized by relatively high 1000 fruit weight as well as high hectoliter mass.

In this study, the seeds of the analyzed crambe genotypes were characterized by high germination capacity which was correlated with weather conditions during the growing cycle. In the wet year of 2017, germination capacity was significantly lower due to a higher proportion of fresh non-germinating seeds. Seed viability was estimated at $97-98 \%$ in all years of the study when the above parameter was taken into account. Dormant seeds were also reported in other crambe genotypes (Costa et al., 2012; Gutormson et al., 1992). In the current study, considerable variation in the proportion of dormant seeds was noted across years, which corroborates the findings of Gutormson et al. (1992). In this study, lines 2, 3 and 4 were characterized by a significantly higher proportion of dormant seeds, and this trait was stable and least sensitive to weather conditions in line 3. Potassium nitrate $\left(\mathrm{KNO}_{3}\right)$ has been recommended by ISTA (2013) for breaking seed dormancy in crambe germination tests. However, Skaggs and Larsen (1969) did not report dormant seeds in any crambe accessions in the USA, they did not confirm the enhancing effect of $\mathrm{KNO}_{3}$ on seed germination, and did not recommend $\mathrm{KNO}_{3}$ in the methodology for 

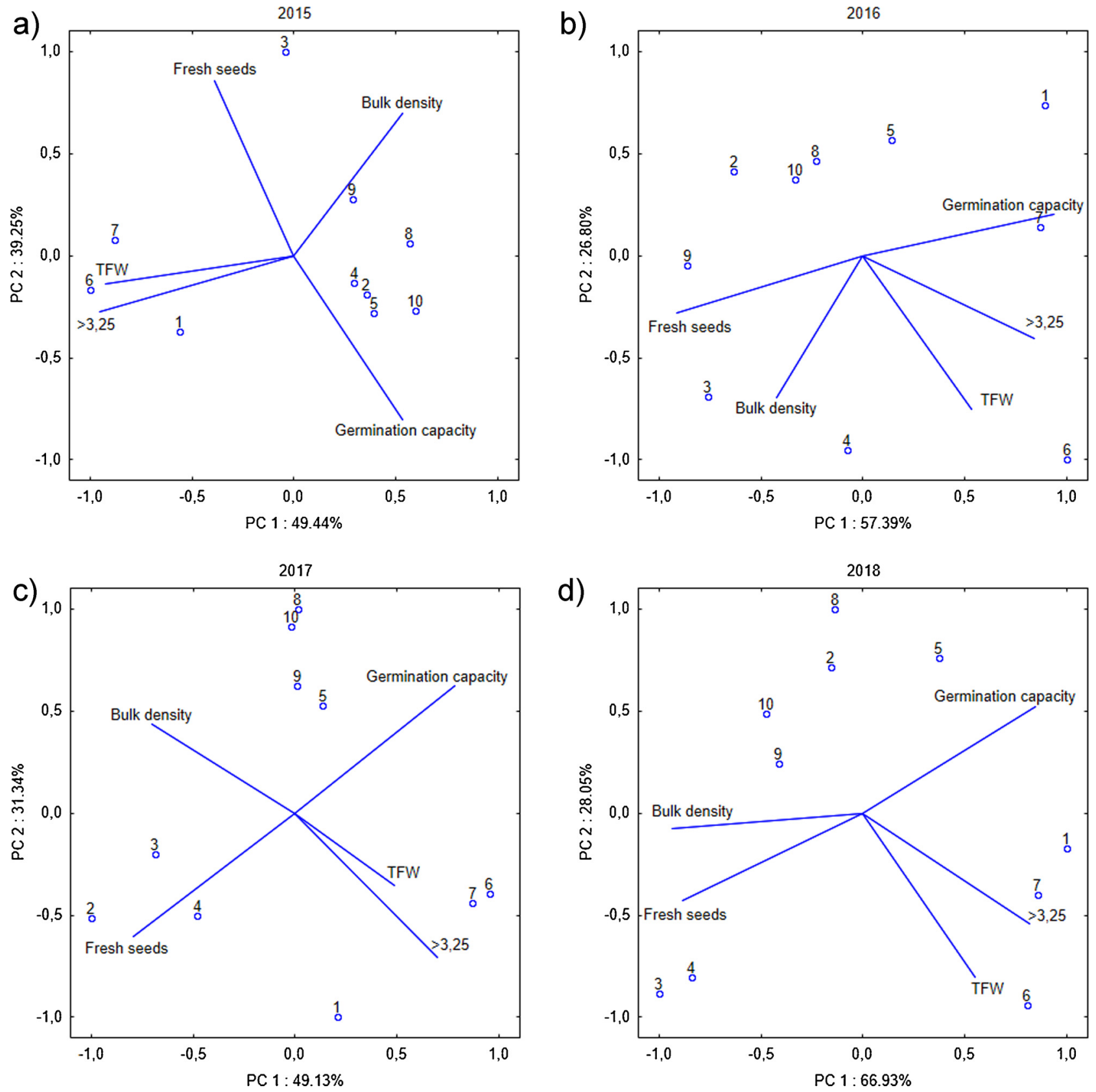

Fig. 4. Principal component analysis (PCA) biplots for selected properties of crambe fruits in four consecutive years of cultivation (2015-2018).

laboratory germination tests for the AOSA. Gutormson et al. (1992) evaluated various laboratory methods for breaking seed dormancy in conventional germination tests and reported that $0.2 \% \mathrm{KNO}_{3}$ solution was most effective in stimulating the germination of freshly harvested crambe seeds. The $\mathrm{KNO}_{3}$ solution did not completely eliminate dormant seeds, but unlike gibberellic acid solution, it had no adverse effect on germination percentage. In a study analyzing the quality of stored crambe seeds, Nunes et al. (2015) observed that the application of $0.2 \%$ $\mathrm{KNO}_{3}$ solution did not affect the results and concluded that this moistening agent should not be used in seeds stored for longer than 9 months. According to Gutormson et al. (1992), the dormancy mechanism of crambe seeds is influenced primarily by physical restrictions. Nunes et al. (2015) ruled out the limiting effect of the pericarp whose removal induced only a minor increase in germination rate. The pericarp is easily removed in an industrial setting, but this operation increases the risk of mechanical seed damage, which could decrease germination capacity, contribute to the spread of fungal infections and compromise seedling health.

Standard germination tests are most widely applied to evaluate the physiological quality of seeds, but they do not provide full information about the health status of seeds and their responses to sub-optimal environmental conditions (Still, 1999). However, according to many authors, germination energy is a robust indicator of the physiological quality of crambe seeds because it describes germination rate, the first parameter that deteriorates with a decrease in seed quality (Leão et al., 2016; Taylor, 2003). In the current study, crambe seeds germinated rapidly, and germination energy was practically identical after 4 and 7 days of germination. Our results clearly contradict other authors' findings who reported considerable differences in germination energy between the first and last day of the germination test (Cruz et al., 2013; Leão et al., 2016; Silva et al., 2016; Soares et al., 2018). These differences could be attributed to the high physiological quality of crambe seeds reproduced in Central-Eastern Europe or variations in the anatomy or physicochemical properties of the pericarp and/or the seed 
coat which determine the rate of seed imbibition and early embryo development.

The controlled deterioration test has been recommended by ISTA (2013) for evaluating seed vigor in the family Brassicaceae. In the test, seeds imbibed to $20 \%$ moisture content are exposed to a temperature of $45^{\circ} \mathrm{C}$ for $24 \mathrm{~h}$ to promote rapid degradation or ageing. The germination capacity of aged or deteriorated seeds is then determined. However, according to Araújo et al. (2017), plant species can respond differently to the test procedure. They demonstrated that the germination capacity of crambe seeds with $18 \%$ moisture content, determined in a 5-day test, was most similar to their field germination capacity. Terra Werner et al. (2013) and Lima et al. (2015) proposed a modified deterioration test for evaluating crambe seed vigor. In the present study, only minor differences in the vigor of seeds harvested in different years of the experiment were noted after the controlled deterioration test. These findings suggest that the viability of crambe seeds remained similar and high, and that the observed differences resulted only from varying proportions of dormant seeds. The controlled deterioration test revealed differences in seed vigor of the evaluated crambe genotypes. Interestingly, large and heavy seeds of genotypes 1, 6 and 7 were characterized by the highest vigor. The test also revealed the low physiological quality of seeds representing genotypes 8 and 9 which were characterized by high germination capacity in the germination test.

The analyzed crambe seeds were characterized by rapid and uniform germination, which prevented an effective evaluation of their germination rates. The first sprouting seeds were observed on the second day of the germination test, and nearly all viable seeds germinated on day 4 . The results were recorded every $24 \mathrm{~h}$, which did not support the determination of differences between genotypes. These findings indicate that the germination of crambe seeds should be evaluated at e.g. hourly intervals, which is difficult to perform in practice, or with the use of machine vision systems (Leão-Araújo et al., 2017).

\section{Conclusion}

The present study demonstrated that crambe grown in north-eastern Europe produces seeds that are characterized by high reproductive value, rapid germination and high viability. The results were used to identify tree breeding lines (Elst2007-2, Elst2007-3 and PRI-9104-71) with large and heavy fruits and high seed vigor. The germination capacity of crambe seeds could have been compromised by adverse weather conditions which shortened the stage of seed formation and ripening, thus increasing the proportion of healthy non-germinating (fresh) seeds. Breeding line Elst2007-16, which produced seeds with desirable physical properties such as high bulk density and mass, was also characterized by a high proportion of fresh seeds regardless of weather conditions. The information about the physical properties of crambe fruits and the physiological quality of seeds could be useful in breeding programs for selecting crambe genotypes with large seeds and high reproductive value.

\section{Declaration of Competing Interest}

The authors declare that they have no known competing financial interests or personal relationships that could have appeared to influence the work reported in this paper.

\section{Acknowledgments}

This work was funded by the European Union Horizon 2020 research and innovation program under grant agreement No. 635405 (COSMOS project). The authors would like to thank the staff of the Department of Plant Breeding and Seed Production and the Didactic and Research Station in Łężany for technical support during the experiment.

\section{References}

Bassegio, D., Zanotto, M.D., Santos, R.F., Werncke, I., Dias, P.P., Olivo, M., 2016. Oilseed crop crambe as a source of renewable energy in Brazil. Renew. Sustain. Energy Rev. 66, 311-321. https://doi.org/10.1016/j.rser.2016.08.010.

Byszewski, W., Ostrowska, D., Pala, J., 1978. Produkcja a Jakość Surowców Roślinnych. PWN, Warszawa.

Carlson, K.D., Gardner, J.C., Anderson, V.L., Hanzel, J.J., 1996. Crambe: New crop Success. In: Janick, J. (Ed.), Progress in New Crops. ASHS Press, Alexandria, VA, pp. $306-322$.

Costa, L.M., Resende, O., Gonçalves, D.N., Souza, K.A., Sales, J.D.F., Donadon, J.R., 2012. The influence of drying on the physiological quality of crambe fruits. Acta Sci. Agron. 34, 213-218. https://doi.org/10.4025/actasciagron.v34i2.12482.

Cruz, S.M., Nery, M.C., Rocha, A.S., Von Pinho, Év.R., Andrade, P.C.R., Dias, D.C.F.S., 2013. Vigor tests for evaluation of crambe (Crambe abyssinica Hochst) seed quality. J. Seed Sci. 35, 485-494. https://doi.org/10.1590/S2317-15372013000400010.

Czabator, F.J., 1962. Germination value: an index combining speed and completeness of pine seed germination. For. Sci. 8, 386-396. https://doi.org/10.1093/forestscience/ 8.4.386.

Dorywalski, j, Goryński, A., Rożnowska, L., Tucholska, H., Wojciechowicz, M., 1956. Nasionoznawstwo Roślin Uprawnych. PWRiL, Warszawa.

Falasca, S.L., Flores, N., Lamas, M.C., Carballo, S.M., Anschau, A., 2010. Crambe abyssinica: an almost unknown crop with a promissory future to produce biodiesel in Argentina. Int. J. Hydrogen Energy 35, 5808-5812. https://doi.org/10.1016/J. IJHYDENE.2010.02.095.

Fontana, F., Lazzeri, L., Malaguti, L., Galletti, S., 1998. Agronomic characterization of some Crambe abyssinica genotypes in a locality of the Po Valley. Eur. J. Agron. 9, 117-126. https://doi.org/10.1016/S1161-0301(98)00037-9.

Grabiec, B., 1958. Prace hodowlano-badawcze nad Crambe abyssinica Hochst (Breeding and research works on Crambe abyssinica Hochst - in Polish). Biul. IHAR 2, 10-16.

Gutormson, T.J., Larson, K.L., Waqar, T., 1992. Germination of freshly harvested and after-ripened crambe (Crambe abyssinica Hochst. Ex. R.E. Fries) seed. J. Seed Technol. 16, 17-23. https://doi.org/10.2307/23432785.

Jankowski, K., Budzyński, W., 2003. Rola elementów struktury plonu w kształtowaniu plonu niektórych jarych roślin oleistych (the role of yield components in the management of yielding of some spring oilseed crops, in Polish with English abstract and conclusion). Rośliny Oleiste - Oilseed Crop XXIV, 443-454.

Lara-Fioreze, A.C., da, C., Pivetta, L.G., Zanotto, M.D., Okita, C.H., Lara-Fioreze, A.C., da, C., Pivetta, L.G., Zanotto, M.D., Okita, C.H., 2016. Genetic variation and gain in progenies of crambe. Crop Breed. Appl. Biotechnol. 16, 132-140. https://doi.org/10. 1590/1984-70332016v16n2a20.

Lara-Fioreze, A.C.C., Tomaz, C.A., Fioreze, S.L., Pilon, C., Zanotto, M.D., 2013. Genetic diversity among progenies of Crambe abyssinica Hochst for seed traits. Ind. Crops Prod. 50, 771-775. https://doi.org/10.1016/J.INDCROP.2013.07.039.

Lazzeri, L., Leoni, O., Conte, L.S., Palmieri, S., 1994. Some technological characteristics and potential uses of Crambe abyssinica products. Ind. Crop. Prod. 3, 103-112. https://doi.org/10.1016/0926-6690(94)90083-3.

Leão-Araújo, E.F., Santos, J.F., Silva, C.B., Marcos-Filho, J., Vieira, R.D., Leão-Araújo, E.F., Santos, J.F., Silva, C.B., Marcos-Filho, J., Vieira, R.D., 2017. Controlled deterioration test and use of the Seed Vigor Imaging System (SVIS ${ }^{\oplus}$ ) to evaluate the physiological potential of crambe seeds. J. Seed Sci. 39, 393-400. https://doi.org/10. 1590/2317-1545v39n4177911.

Leão, É.F., dos Santos, J.F., Barbosa, R.M., Vieira, R.D., 2016. Accelerated ageing as a vigour test for crambe (Crambe abyssinica) seeds. Aust. J. Crop Sci. 10, 660-665. https://doi.org/10.21475/ajcs.2016.10.05.p7359.

Lessman, K.J., 1990. Crambe: a New industrial crop in limbo. In: Janick, J., Simon, J.E (Eds.), Advances in New Crops. Timber Press, Portland, OR, pp. 217-222.

Lima, J.J.P., Freitas, M.Nde, Guimarães, R.M., Vieira, A.R., Ávila, M.A.B., Lima, J.J.P., Freitas, M.Nde, Guimarães, R.M., Vieira, A.R., Ávila, M.A.B., 2015. Accelerated aging and electrical conductivity tests in crambe seeds. Ciência e Agrotecnologia 39, 7-14. https://doi.org/10.1590/S1413-70542015000100001.

Maguire, J.D., 1962. Speed of germination-aid in selection and evaluation for seedling emergence and Vigor1. Crop Sci. 2, 176. https://doi.org/10.2135/cropsci1962. 0011183X000200020033x.

Mastebroek, H., Lange, W., 1997. Progress in a crambe cross breeding programme. Ind. Crops Prod. 6, 221-227. https://doi.org/10.1016/S0926-6690(97)00011-3.

Meijer, W.J.M., Mathijssen, E.W.J.M., Kreuzer, A.D., 1999. Low pod numbers and inefficient use of radiation are major constraints to high productivity in Crambe crops. Ind. Crops Prod. 9, 221-233. https://doi.org/10.1016/S0926-6690(98)00035-1.

Młodzianowska, D., 1961. Nasionoznawstwo. PWRiL, Warszawa.

Nunes, A.D.S., Souza, L.C.Fde, Scalon, S.D.P.Q., Pagnoncelli, J., Pagnoncelli, J., 2015. Nitrato de potássio e retirada do pericarpo na germinação e na avaliação do vigor de sementes de crambe. Semin. Ciências Agrárias 36, 1775. https://doi.org/10.5433/ 1679-0359.2015v36n3Supl1p1775.

Oliveira, M.B., David, A.M.S.S., Amaro, H.T.R., Assis, M.D.O., Rodrigues, B.R.A., Aspiazú, I., Carvalho, A.J., Carvalho, A.J., 2014. Épocas de colheita e qualidade fisiológica de sementes de crambe. Semin. Ciências Agrárias 35, 1785. https://doi.org/10.5433/ 1679-0359.2014v35n4p1785.

Oliveira, R.L., Dias, L.A.S., Corrêa, T.R., Ferreira, P.H.S., Silva, M.F., Oliveira, R.L., Dias, L.A.S., Corrêa, T.R., Ferreira, P.H.S., Silva, M.F., 2018. Divergence and estimates of genetic parameters in Crambe abyssinica: an oilseed plant for industrial uses. Rev. Ceres 65, 500-506. https://doi.org/10.1590/0034-737x201865060005.

PN EN ISO 7971-3, 2010. Cereals - Determination of Bulk Density, Called Mass Per Hectolitre - Part 3: Routine Method. Polish Committee for Standardization.

Prakhova, T.Y.A., 2013. New non-traditional oil-crops - Abyssinian Crambe (in Russian). 
Bull. Altai State Agrar. Univ. 8 (106), 8-10.

Selyaninov, G.T., 1928. About agricultural assessment of climate. Contrib. to Agric. Meteorol XX, 165-177.

Silva, M.A.Pda, Lima, J.J.P., Biaggioni, M.A.M., Cavariani, C., Ferreira, G., Silva, M.A.Pda, Lima, J.J.P., Biaggioni, M.A.M., Cavariani, C., Ferreira, G., 2016. Seed quality of crambe (Crambe abyssinica Hochst) submitted to different drying methods. Rev. Ciência Agronômica 47, 358-365. https://doi.org/10.5935/1806-6690. 20160042.

Skaggs, D.P., Larsen, A.L., 1969. Recommendation for germination of crambe seed. Proc. Assoc. Off. Seed Anal. https://doi.org/10.2307/23432356.

Skowera, B., 2014. Changes of hydrothermal conditions in the Polish area (1971-2010) (in Polish). Fragm. Agron. 31, 74-87.

Soares, T.F.S.N., Freitas, B.A.L., Filho, J.G.A.F., Dias, D.C.F.S., Fialho, C.A., Medeiros, A.D., Oliveira, R.M., Oliveira, A.S., 2018. Assessment of seed vigor tests for Crambe abyssinica. J. Agric. Sci. 10, 527. https://doi.org/10.5539/jas.v10n12p527.

Still, D.W., 1999. The development of seed quality in Brassicas. Horttechnology 9 335-340. https://doi.org/10.21273/HORTTECH.9.3.335.

Stolarski, M.J., Krzyżaniak, M., Kwiatkowski, J., Tworkowski, J., Szczukowski, S., 2018. Energy and economic efficiency of camelina and crambe biomass production on a large-scale farm in north-eastern Poland. Energy 150, 770-780. https://doi.org/10. 1016/J.ENERGY.2018.03.021.

Taylor, A.G., 2003. Seed development | seed quality. Encycl. Appl. Plant Sci. 1285-1291. https://doi.org/10.1016/B0-12-227050-9/00056-9.

Terra Werner, E., Carlos Lopes, J., Gomes Junior, D., Luber, J., Teixeira do Amaral, J.A.,
2013. Accelerated aging test to evaluate the quality of crambe (Crambe abyssinica Hochst - Brassicaceae) seed physiology. Idesia 31, 35-43. https://doi.org/10.4067/ S0718-34292013000100005.

TIBCO Software Inc, 2017. Statistica (data Analysis Software System), Version 13. http:// statistica.io.

Vollmann, J., Ruckenbauer, P., 1993. Agronomic performance and oil quality of crambe as affected by genotype and environment. Die Bodenkultur - J. L. Manag. Food Environ. 44, 335-343.

Wang, Y.P., Tang, J.S., Chu, C.Q., Tian, J., 2000. A preliminary study on the introduction and cultivation of Crambe abyssinica in China, an oil plant for industrial uses. Ind. Crop. Prod. 12, 47-52. https://doi.org/10.1016/S0926-6690(99)00066-7.

Wilhite, D.A., Pulwarty, R.S., 2017. Drought and Water Crises: Integrating Science, Management, and Policy, second edition ed. CRC Press.

Wolff, I.A., 1966. New crops-visionary dream or practical reality? Econ. Bot. 20, 2-5. https://doi.org/10.1007/BF02861921.

Zanetti, F., Monti, A., Berti, M.T., 2013. Challenges and opportunities for new industria oilseed crops in EU-27: a review. Ind. Crops Prod. 50, 580-595. https://doi.org/10. 1016/J.INDCROP.2013.08.030.

Zanetti, F., Scordia, D., Vamerali, T., Copani, V., Dal Cortivo, C., Mosca, G., 2016. Crambe abyssinica a non-food crop with potential for the Mediterranean climate: insights on productive performances and root growth. Ind. Crops Prod. 90, 152-160. https://doi. org/10.1016/j.indcrop.2016.06.023.

Zhu, L.-H., 2016. Crambe (Crambe abyssinica). Ind. Oil Crop. 195-205. https://doi.org/ 10.1016/B978-1-893997-98-1.00007-5. 